\title{
Attenuation of visceral pain in mice by the essential oil from Vanillosmop- sis arborea bark*
}

\section{O óleo essencial do caule de Vanillosmopsis arborea atenua a dor visceral em camun- dongos}

Gerlânia de Oliveira Leite ${ }^{1}$, Renata Souza Sampaio², Laura Hévila Inocêncio Leite ${ }^{3}$, Irwin Rose Alencar de Menezes ${ }^{4}$, José Galberto Martins da Costa ${ }^{4}$, Adriana Rolim Campos ${ }^{5}$

${ }^{*}$ Received from University of Fortaleza, CE.

\section{SUMMARY}

BACKGROUND AND OBJECTIVES: Vanillosmopsis arborea Baker (Asteraceae) has high economic value and anti-inflammatory properties due the presence of alpha-bisabolol in its bark essential oil. Keeping in view the high content of $\alpha$-bisabolol in Vanillosmopsis arborea (EOVA) bark essential oil, the aim of our study was to determine whether EOVA mitigates visceral nociception induced by different noxious agents.

METHOD: Mice $(\mathrm{n}=8)$ were pretreated orally with EOVA (100, 200 e $400 \mathrm{mg} / \mathrm{kg}$ ) or vehicle, and pain-related behavioral responses to intraperitoneal cyclophosphamide (CPM $400 \mathrm{mg} / \mathrm{kg}$ ), intracolonic mustard oil (MO $0.75 \%$ ) or capsaicin (CAP $0.3 \%$ ) were analyzed.

RESULTS: Animals that received CFM, OM or CAP presented spontaneous nociceptive behaviors that were significantly suppressed by EOVA.

1. MSc student in Molecular Bioprospection at Regional University of Cariri, Crato, CE, Brazil.

2. Researcher of Regional University of Cariri. Crato, CE, Brazil.

3. Student of Biological Sciences at Regional University of Cariri, Crato, CE, Brazil.

4. Professor of Regional University of Cariri. Crato, CE, Brazil.

5. Professor of University of Fortaleza. Fortaleza, CE, Brazil.

Address of correspondence:

Adriana Rolim Campos

Vice-Rectory of Research and Post-Graduation

University of Fortaleza

Av. Washington Soares, 1321

60811-905 Fortaleza, CE, Brazil.

Phone: +55 8534773274 - Fax: +55 8534773056

E-mail: adrirolim@unifor.br
CONCLUSION: These findings point to visceral antinociceptive properties of EOVA suggesting the potential use of Vanillosmopsis arborea to treat pain associated to gastrointestinal disorders.

Keywords: Essential oil, Vanillosmopsis arborea, Visceral pain.

\section{RESUMO}

JUSTIFICATIVA E OBJETIVOS: Vanillosmopsis arborea Baker (Asteraceae) de reconhecido valor econômico que possui propriedades anti-inflamatórias provenientes do sesquiterpeno alfa-bisabolol, presente em teores elevados no óleo essencial de sua madeira. Considerando-se o alto teor de $\alpha$-bisabolol no óleo essencial do caule de Vanillosmopsis arborea (OEVA). O objetivo deste estudo foi determinar o efeito do OEVA na nocicepção visceral induzida por diversos agentes irritantes. MÉTODO: Camundongos $(\mathrm{n}=8)$ foram pré-tratados por via oral com EOVA $(100,200$ e $400 \mathrm{mg} / \mathrm{kg}$ ) ou veículo e as respostas comportamentais devido a administração de ciclofosfamida (CFM $400 \mathrm{mg} / \mathrm{kg}$; por via intraperitoneal), óleo de mostarda (OM 0,75\%; intracolônico) ou capsaicina (CAP 0,3\%; intracolônica) foram registradas.

RESULTADOS: Os animais que receberam CFM, OM ou CAP manifestaram comportamentos nociceptivos espontâneos que foram significativamente suprimidos nos grupos tratados com OEVA.

CONCLUSÃO: Estes achados apontam a propriedade antinociceptiva visceral do óleo essencial do caule de Vanillosmopsis arborea indicando o uso potencial no alívio da dor associada às desordens gastrintestinais.

Descritores: Dor visceral, Óleo essencial, Vanillosmopsis arborea. 


\section{INTRODUCTION}

Vanillosmopsis arborea Baker, popular known as "candeeiro", is a small tree which grows in the Araripe National Forest, in the state of Ceará, Brazil. Its wood has a strong odor of chamomile and burns easily with a strong flame ${ }^{1}$. Phytochemical studies of the essential oil revealed the presence of a high content of bisabo$\mathrm{lol}^{2}$ and experimental investigations demonstrated the gastroprotective $^{3}$, larvicidal ${ }^{4}$, antimicrobial, antifungical and anti-inflammatory activities ${ }^{5}$ and it is popularly used as a repellent. Earlier studies indicated that candeeiro is not potentially toxic ${ }^{6}$.

Visceral pain is the most common form of pain for which the patients often seek medical care. Despite the considerable advances in knowledge regarding the basic mechanisms underlying the visceral pain and visceral hyperalgesia, no new effective therapies for abdominal pain have been discovered. So far, there is no experimental evidence indicating a visceral antinociceptive activity of Vanillosmopsis arborea essential oil. An analgesic effect of "candeeiro" using the acetic acid-induced writhing test has been described earlier ${ }^{7}$, but not considered a valid model of visceral nociception since it affects unknown somatic and visceral structures ${ }^{8}$. An alternative model of acute visceral pain in the mouse employs the intracolonic instillation of capsaicin, mustard oil or formalin or intraperitoneal cyclophosphamide, that produce visceral pain-related behaviors such as licking of the abdomen, stretching the abdomen, squashing of the lower abdomen against the floor and abdominal retractions, which can be quantified ${ }^{8,9}$.

Keeping in view the high content of alpha-bisabolol in Vanillosmopsis arborea bark essential oil, the aim of our study was to determine whether Vanillosmopsis arborea mitigates visceral nociception-induced by different noxious agents.

\section{METHOD}

\section{Plant material}

The essential oil from Vanillosmopsis arborea Baker bark (EOVA) was obtained at the Natural Products Research Laboratory of Regional University of Cariri the composition $(w / w)$ of EOVA revealed the presence of $\alpha$-bisabolol to extent of $70 \%$. Others identified compounds were $\alpha$-cadinol (8.4\%), elemicine (6.21\%), $\beta$-bisabolene (4.46\%), $\delta$-guaiene $(2.31 \%), \beta$-cubebene $(1.76 \%)$ and estragole $(1.08 \%)$.

\section{Animals}

Male Swiss albino mice (20-25 g) obtained from the Central Animal House of Regional University of Cariri were used. They were housed in environmentally controlled conditions $\left(22^{\circ} \mathrm{C}, 12 \mathrm{~h}\right.$ light-dark cycle), with free access to standard pellet diet (Purina, São Paulo, Brazil) and water. Animals were kept in cages with raised floors to prevent coprophagy. They were fasted over a period of 15 $\mathrm{h}$ and were habituated to the test environment for $2 \mathrm{~h}$ before the experimentation. The experimental protocols were approved by the Animal Care and Use Committee of the University of Fortaleza in accordance with the ethical guidelines of National Institute of Health, Bethesda, U.S.A.

\section{Cyclophosphamide-induced visceral nociception}

Mice divided in groups ( 8 in each) were treated with vehicle ( $2 \%$ Tween 80 in distillated water, $10 \mathrm{ml} / \mathrm{kg}$, p.o.) or EOVA (100, 200 or $400 \mathrm{mg} / \mathrm{kg}$, p.o.), $1 \mathrm{~h}$ before the intraperitoneal administration of cyclophosphamide (CPM, $400 \mathrm{mg} / \mathrm{kg}$ ). Immediately after CPM or saline injection, each animal was examined for the time spent in expressing the visceral nociceptive behaviors (transient crises) like piloerection, licking the abdomen, squashing of the abdomen against the floor and the abdominal contortions and retractions) during a $4 \mathrm{~h}$ period. A normal control, that received only saline intraperitoneally, was included in the study.

\section{Mustard oil-induced visceral nociception}

To assess the antinociceptive effect of EOVA against the mustard oil (MO)-induced visceral nociception, mice in groups $(n=8)$ were orally treated with EOVA $(100,200$ or $400 \mathrm{mg} / \mathrm{kg})$ or vehicle (2\% Tween 80 in distillated water, $10 \mathrm{ml} / \mathrm{kg}$, p.o.) $1 \mathrm{~h}$ before the intracolonic administration of $\mathrm{MO}(0.75 \%$ in saline $0.9 \%, 50 \mu \mathrm{l} /$ animal $)$. A group of normal control received a similar dose of saline $(10 \mathrm{~mL} /$ $\mathrm{kg}$ ). Immediately following the intracolonic $\mathrm{MO}$ or saline administration, the mice were observed of the total number of nociceptive behaviors (licking the upper abdomen, stretching the abdomen, squashing the abdomen against the floor and retraction of the abdomen characterized for an arched position), for a $20 \mathrm{~min}$ period.

\section{Capsaicin-induced visceral nociception}

Male mice divided into groups of eight in each were pretreated with the vehicle ( $2 \%$ Tween 80 in distillated water, $10 \mathrm{ml} / \mathrm{kg}$, p.o.) or EOVA (100, 200 or $400 \mathrm{mg} / \mathrm{kg}$, p.o.). One hour after oral and 30 min following systemic treatments, capsaicin $(0.3 \%$ in a solution of PBS: Tween 80 : ethanol (8:1:1) was instilled into the colon $(50 \mu 1 /$ animal $)$ 
using a fine cannula (1.6 mm external diameter), $4 \mathrm{~cm}$ far from the anal sphincter. Solid petroleum jelly was applied onto the perianal region to avoid local nerve stimulation. The animals were then observed during a $30 \mathrm{~min}$ period for the spontaneous visceral pain-related behaviors (licking the upper abdomen, abdominal contortion and retraction, squashing the abdomen against the floor). A normal group, that received only saline intracolonically, was also included.

\section{Statistical analysis}

The results are expressed as mean \pm S.E.M. from 8 mice per group. For statistical analysis, ANOVA followed by Student Newman Keul's post hoc test, as appropriate were used. A p $<0.05$ was considered statistically significant.

\section{RESULTS}

Graphics 1, 2 and 3 show the antinociceptive effect of EOVA in cyclophosphamide, mustard oil and capsaicin tests. Intraperitoneal application of cyclophosphamide (CFM $400 \mathrm{mg} / \mathrm{kg}$ ) and intracolonic application of mustard oil (MO 0.75\%), and capsaicin (CAP 0.3\%), provoked a significant increase in spontaneous pain-related behaviors when compared with saline treated normal controls. In groups pretreated with EOVA, cyclophosphamide, mustard oil and capsaicin-induced nociceptive behaviors were significantly inhibited.

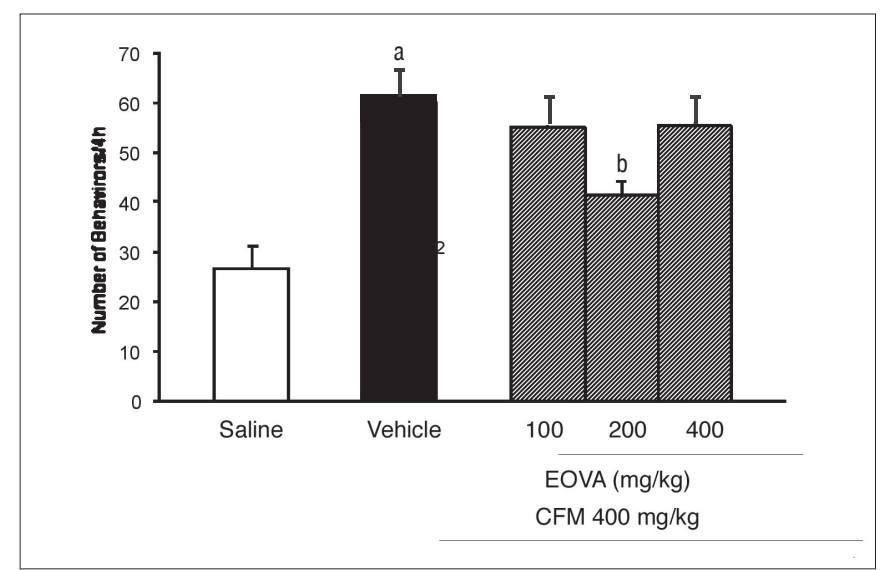

Graphic 1 - The antinociceptive effect of EOVA against cyclophosphamide-induced visceral nociception in mice. Pain-related behaviors (piloerection, licking the abdomen, squashing of the abdomen against the floor and the abdominal contortions and retractions)-evoked by intraperitoneal cyclophosphamide (CFM $400 \mathrm{mg} / \mathrm{kg}$ ) were observed in the $4 \mathrm{~h}$ post-administration in mice pretreated with vehicle or Vanillosmopsis arborea (EOVA, 100, 200, $400 \mathrm{mg} / \mathrm{kg}$, p.o.). Data represent the mean \pm S.E.M. $(n=8)$.

${ }^{\mathrm{a}} \mathrm{p}<0.001$ versus saline; ${ }^{\mathrm{b}} \mathrm{p}<0.001$ versus vehicle-treated group that received cyclophosphamide.



Graphic 2 - Effect of EOVA on nociception induced by intracolonic mustard oil $(0.75 \%)$ in mice. Pain-related behaviors (piloerection, licking the abdomen, squashing of the abdomen against the floor and the abdominal contortions and retractions)-evoked by intracolonic mustard oil (MO $0.75 \%$ ) were observed in the $4 \mathrm{~h}$ post-administration in mice pre-treated with vehicle or Vanillosmopsis arborea (EOVA, $100,200,400 \mathrm{mg} / \mathrm{kg}$, p.o.). Data represent the mean \pm S.E.M. $(\mathrm{n}=8)$. ${ }^{\mathrm{a}} \mathrm{p}<0.001$ versus saline; ${ }^{\mathrm{b}} \mathrm{p}<0.001$ versus vehicle-treated group that received mustard oil.

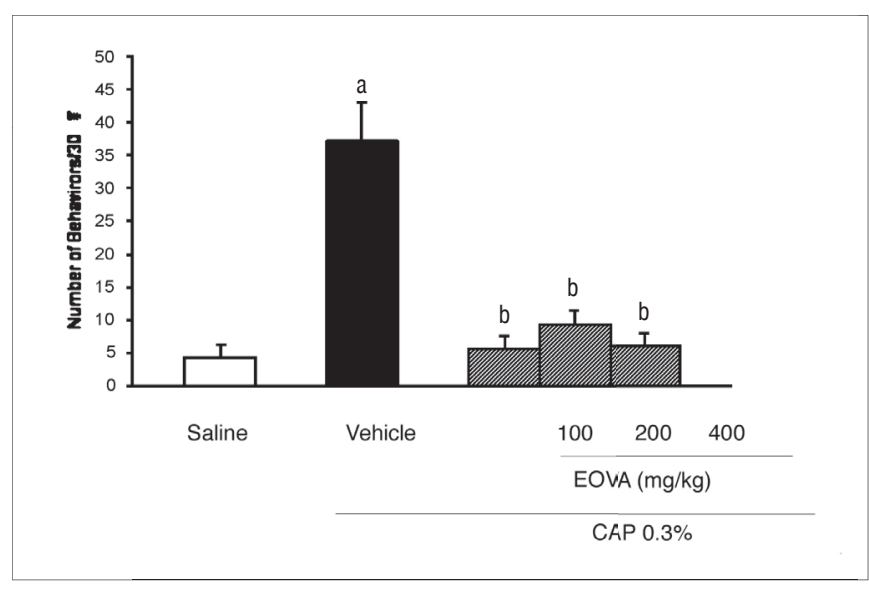

Graphic 3 - Effect of EOVA on nociception induced by intracolonic capsaicin $(0.3 \%)$ in mice. Pain-related behaviors (piloerection, licking the abdomen, squashing of the abdomen against the floor and the abdominal contortions and retractions)-evoked by intracolonic capsaicin (CAP $0.3 \%$ ) were observed in the $30 \mathrm{~min}$ post-administration in mice pre treated with vehicle or Vanillosmopsis arborea (EOVA, $100,200,400 \mathrm{mg} / \mathrm{kg}$, p.o.). Data represent the mean \pm S.E.M. $(\mathrm{n}=8)$. ${ }^{\mathrm{a}} \mathrm{p}<0.001$ versus saline; ${ }^{\mathrm{b}} \mathrm{p}<0.001$ versus vehicle-treated group that received capsaicin.

\section{DISCUSSION}

In animals several algogenic substances like capsaicin, mustard, and cyclophosphamide, applied to visceral structures can elicit pain-related behaviors involving capsaicin sensitive primary afferents ${ }^{9}$. These algogenic substances 
are capable of inducing pain as well as inflammatory reaction when either visceral afferents are sensitized or central neurons undergo a change in excitability (central sensitization) after persistent visceral input ${ }^{10}$. In the search for novel natural substances, which possess visceral antinociceptive property, we used the acute models of visceral pain induced by intraperitoneal administration of acetic acid or cyclophosphamide or by intracolonic instillation of mustard oil, capsaicin or formalin to produce spontaneous pain-related behaviors in mice, which has disease-relevancy to human irritable bowel syndrome.

The essential oil of Vanillosmopsis arborea could significantly suppress the pain-related behaviors against all noxious agents used to induce visceral pain, possibly regulating the functioning of primary afferent fibers. Visceral afferents express a wide range of membrane receptors (including vanilloid receptors, TRPV1) to chemical stimuli, which are involved in sensory signaling from the gut to the central nervous system ${ }^{11}$. This antinociceptive effect may be related to the high bisabolol content in EOVA, since that Alves et al. ${ }^{12}$ have just reported that bisabolol is able to reduce the neuronal excitability in a concentration-dependent manner.

\section{CONCLUSION}

In conclusion, we provided in vivo evidence to show that EOVA inhibits visceral nociception induced by several agents, which needs further elucidation on its antinociceptive activity.

\section{REFERENCES}

1. Matos MEO, Sousa MP, Matos FJA, et al. Sesquiterpenes from Vanillosmopsis arborea. J Nat Prod 1998;51:780-2.

2. Kamatou GPP, Viljoen AM. A review of the application and pharmacological properties of $\alpha$-bisabolol and $\alpha$-bisabolol-rich oils. J Am Oil Chem Soc 2010;87(1):1-7. 3. de O Leite G, da Penha AR, Fernandes CN, et al. Gastroprotective mechanism of Vanillosmopsis arborea bark essential oil. Fitoterapia 2009;80(1):77-80.

4. Furtado RF, Lima MGA, Andrade Neto M, et al. Atividade larvicida de óleos essenciais contra Aedes aegypti L. (diptera: culicidae). Neotrop Entomol 2005;34(5):843-7.

5. Lima IVM, Silva MGV, Cavalcanti FS. Estudo químico de Vanillosmopsis arborea - Fonte Cearense de $\alpha$-bisabolol. in: XLVI Congresso Brasileiro de Química $-46^{\circ}$ CBQ, Salvador, Livro de Resumos; 2006.

6. Mota ML. Atividade antimalárica de plantas medicinais da biorregião do Araripe-CE um modelo murino Plasmodium beghei. Dissertação de Mestrado. Programa de Pós-Graduação em Ciências Biológicas, Universidade Federal da Paraíba, Brasil; 2009.

7. Santos NKA, Verificação das Propriedades Antibacteriana e Farmacológica do Óleo Essencial de Vanillosmopsis arborea (Asteraceae) Baker. Dissertação de Mestrado. Programa de Pós-Graduação em Bioprospecção Molecular, Universidade Regional do Cariri, Brasil; 2009.

8. Laird JM, Martinez-Caro L, Garcia-Nicas E, et al. A new model of visceral pain and referred hyperalgesia in the mouse. Pain 2001;92(3):335-42.

9. Jiang MC, Gebhart GF. Development of mustard oil-induced hyperalgesia in rats. Pain 1998;77(3):305-13.

10. Olivar T, Laird JM. Cyclophosphamide cystitis in mice: behavioural characterisation and correlation with bladder inflammation. Eur J Pain 1999;3(2):141-9.

11. Maggi CA, Lecci A, Santicioli P, et al. Cyclophosphamide cystitis in rats: involvement of capsaicin-sensitive primary afferents. J Auton Nerv Syst 1992;38(3):201-8.

12. Alves Ade M, Gonçalves JC, Cruz JS, et al. Evaluation of the sesquiterpene (-)-alpha-bisabolol as a novel peripheral nervous blocker. Neurosci Lett 2010;472(1):1-5. 13. Wood JN. Recent advances in understanding molecular mechanisms of primary afferent activation. Gut 2004;53(Suppl 2):9-12.

Presented in November 14, 2010.

Accepted in March 28, 2011. 